Jurnal SPORTIF: Jurnal Penelitian Pembelajaran

Vol. 6 No. 2, Agustus 2020, pp. 407-422

doi) https://doi.org/10.29407/js_unpgri.v6i2.14462

\title{
Evaluasi penerapan blended learning berdasarkan kualitas model dan motivasi belajar mahasiswa-atlet
}

\section{Evaluation of the blended learning implementation based on model quality and student-athlete learning motivation}

\author{
Vega Candra Dinata ${ }^{1}$, Anung Priambodo ${ }^{2}$, Agus Hariyanto ${ }^{3}$, Kolektus \\ Oky Ristanto ${ }^{4}$, dan Bayu Budi Prakoso ${ }^{5}$
}

1,2,3,4,5Fakultas IImu Olahraga, Universitas Negeri Surabaya, Jl. Raya Kampus Unesa, Lidah Wetan, Kec. Lakarsantri, Kota Surabaya, Provinsi Jawa Timur 60213, Indonesia

Received: 10 June 2020; Revised: 19 June 2020; Accepted: 3 July 2020

\begin{abstract}
Abstrak
Penelitian deskriptif ini bertujuan mengevaluasi penerapan blended learning berbasis schoology berdasarkan kualitas model dan motivasi belajar mahasiswaatlet dalam kegiatan diseminasi produk penelitian dan pengembangan. Empat universitas bersedia menjadi tempat diseminasi dengan jumlah mahasiswa-atlet yang terlibat sebanyak 59 orang (39 laki-laki dan 20 perempuan). Kualitas model diukur menggunakan angket untuk mengungkap utility, feasibility, accuracy, dan propriety. Sedangkan motivasi diukur menggunakan angket untuk mengungkap motivasi intrinsik dan ekstrinsik. Content validity ratio (CVR) dan persentase digunakan untuk menganalisis kualitas model. Data motivasi dianalisis menggunakan deskriptif statistik, $t$-test, dan One-Way Anova. Hasil penelitian menunjukkan bahwa syarat validitas pengukuran kualitas model berdasarkan utility, feasibility, accuracy, dan propriety telah terpenuhi dengan nilai rata-rata indeks CVR sebesar 0.98 dan nilai kualitas sebesar 92\% (baik sekali). Motivasi intrinsik masuk dalam kategori baik (47.3), ekstrinsik masuk dalam kategori baik (67.1), dan motivasi total masuk dalam kategori baik (114.4). Motivasi mahasiswa-atlet ditinjau dari daerah $(F(3,55)=0.451, p=0.718)$, gender $(t(57)=$ $0.714, \mathrm{p}=0.478)$, dan jenis cabang olahraga $(\mathrm{t}(57)=0.531, \mathrm{p}=0.597)$ dinyatakan sama. Artinya, model blended learning berbasis schoology dapat memelihara motivational climate untuk mahasiswa-atlet dalam berbagai kondisi dan jenis latar belakang.
\end{abstract}

Kata kunci: motivasi, mahasiswa-atlet, blended learning, schoology.

\begin{abstract}
The purpose of this descriptive study was to evaluate the implementation of schoology-based blended learning model. This was carried out based on the quality of the model and student-athlete learning motivation in the dissemination of research and development products. Four universities were used as locations for dissemination with 59 student-athletes involved (39 male and 20 female). The model quality was measured using a questionnaire to reveal utility, feasibility, accuracy, and propriety. Meanwhile, motivation was measured using a questionnaire to reveal the intrinsic and extrinsic motivation. Content validity ratio (CVR) and percentage were used to analyze the model quality. The motivation data was analyzed using descriptive statistics, $t$-tests, and One-Way analysis of variance (ANOVA). The results of this study showed that the validity,
\end{abstract}

Correspondence author: Bayu Budi Prakoso, Universitas Negeri Surabaya, Indonesia.

Email: bayuprakoso@unesa.ac.id 
requirements of the model quality measurements based on utility, feasibility, accuracy, and propriety were fulfilled with an average CVR index of 0.98 and a quality value of $92 \%$ (very good). Furthermore, intrinsic, extrinsic, and total motivations were included in good categories with values of 47.3, 67.1, and 114.4 , respectively. In addition, student-athlete motivation by region $(F(3,55)=$ $0.451, p=0.718$ ), gender ( $t(57)=0.714, p=0.478)$, and type of sport ( $t(57)=$ $0.531, p=0.597)$ were the same. Therefore, this implies that the schoologybased blended learning model maintained a motivational climate for studentathletes in a variety of conditions and backgrounds.

Keywords: motivation, student-athlete, blended learning, schoology.

\section{PENDAHULUAN}

Pembalajaran tradisional tatap muka diyakini tidak akan berlangsung lama, tetapi masalah yang terjadi di Indonesia, penggunaan teknologi untuk keperluan pembelajaran masih rendah (Wuryaningsih, Susilastuti, Darwin, \& Pierewan, 2019). Padahal dominasi headline pengembangan pendidikan dalam dua dekade ini berisi tentang pembelajaran jarak jauh yang diintegrasi dengan teknologi dan informasi yang sangat tergantung pada internet (Huba \& Kozák, 2016). Hal tersebut menunjukkan bahwa betapa Indonesia masih memiliki masalah besar dalam mewujudkan pembelajaran yang berbasis teknologi dan informasi dalam menghadirkan pembelajaran jarak jauh untuk memfasilitasi pembelajar yang memiliki kesulitan dalam menghadiri pembelajaran tatap muka.

Di perguruan tinggi, pembelajar yang sering mengalami kesulitan tatap muka adalah mereka yang memiliki peran ganda, yaitu mahasiswaatlet. Mereka harus belajar akademik sekaligus menjalani program latihan bahkan tidak jarang di luar universitas. Dengan kondisi tersebut, diyakini mereka cenderung memiliki manajemen yang kurang baik dibandingkan dengan mahasiswa non-atlet akibat padatnya aktivitas mereka (Riciputi \& Erdal, 2017; Sandstedt et al., 2004). Selain itu, mereka juga memiliki motivasi dan prestasi akademik yang berbeda dengan mahasiswa nonatlet (Pedescleaux, 2010). Temuan penelitian lainnya menunjukkan bahwa mahasiswa-atlet memiliki performa akademik yang rendah akibat dari sering terjadinya konflik antara perannya sebagai mahasiswa yang baik atau mengikuti aktivitas sebagai atlet (Levine et al., 2014). Menjaga 
tingginya motivasi menjadi salah satu kunci pengajar dalam menjaga harapan berprestasi kepada mahasiswa-atlet dalam cabang olahraga dan akademik (Ibrahim, Jaafar, Kassim, \& Isa, 2016). Hasil penelitian lainnya tentang penelusuran kebutuhan belajar mahasiswa-atlet menyebutkan bahwa pimpinan perguruan tinggi perlu memberikan dukungan kepada mahasiswa-atlet berupa fasilitas pembelajaran yang sesuai dengan kebutuhan mahasiswa-atlet berupa layanan pembelajaran jarak jauh agar mereka dapat mengikuti proses latihan sebagai atlet sekaligus kegiatan belajar di bidang akademik sebagai mahasiswa (Priambodo et al., 2020). Untuk itu, perguruan tinggi memiliki peran penting dalam memberikan fasilitas layanan pendidikan yang dapat membantu mahasiswa-atlet dapat tuntas dalam menjalani proses akademik maupun menjadi top atlet.

Perkuliahan dengan menerapkan blended learning dianggap menjadi pilihan jitu dalam memfasilitasi mahasiswa-atlet karena dapat menyediakan pendidikan yang mudah, terlepas dari ruralitas, lokalitas, dan ketertinggalan (Best \& MacGregor, 2017). Selain itu, penerapan blended learning telah terbukti dapat mendukung berlangsungnya pendidikan sepanjang hayat, membentuk lingkungan belajar yang ramah, menghemat sumber daya, dan menghilangkan kesenjangan dalam proses pembelajaran (Yao, 2019). Secara umum, blended learning merupakan proses pembelajaran yang mengintegrasikan proses pembelajaran tradisional (tatap muka) dengan pembelajaran digital online (Gaol \& Hutagalung, 2020). Blended learning menjadi trending dalam institusi pendidikan tinggi secara global (Ibrahim \& Nat, 2019) karena perguruan tinggi menjadi institusi yang dianggap banyak menerapkannya (Atmacasoy \& Aksu, 2018; Castro, 2019; Kabassi et al., 2016). Penerapan blended learning dapat dikemas dengan memanfaatkan Learning Management System (LMS) dalam mengombinasikan pembelajaran daring, tatap muka, dan pengalaman belajar dari dunia nyata (Lim et al., 2019). Beberapa contoh jenis LMS yaitu moddle, edmodo, dan schoology.

Blended learning dalam artikel ini adalah berbasis schoology sebagai LMS yang memiliki banyak pilihan fitur layanan pembelajaran 
Vega Candra Dinata, Anung Priambodo, Agus Hariyanto, Kolektus Oky Ristanto, dan Bayu

Budi Prakoso

Evaluasi penerapan blended learning berdasarkan kualitas model dan motivasi belajar mahasiswaatlet

dibandingkan dengan yang lainnya. Schoology didefinisikan sebagai sistem manajemen pembelajaran yang tersedia secara gratis yang menawarkan banyak platform untuk menyediakan pendidikan online sebagai upaya kolektif antara pengajar dan pembelajar untuk lebih aktif terlibat dalam kegiatan pembelajaran (Sarrab et al., 2018). Fitur-fitur yang tersedia dalam schoology yaitu (1) courses (kursus), yaitu fasilitas untuk membuat kelas mata kuliah; (2) groups (kelompok), yaitu fasilitas untuk membuat kelompok; dan (3) resources (sumber belajar), yaitu fasilitas untuk menyediakan sumber belajar untuk peserta perkuliahan.

Pemanfaatan blended learning berbasis schoology yang dimaksud dalam artikel ini adalah produk hasil penelitian dan pengembangan yang telah terbukti valid dan efektif dalam meningkatkan motivasi belajar mahasiswa-atlet FIO Unesa yang sedang mengikuti PELATNAS untuk berbagai cabang olahraga (Priambodo, Hariyanto, \& Dinata, 2020). Untuk lebih mengetahui proses blended learning di berbagai universitas maka produk hasil pengembangan tersebut didiseminasikan untuk universitas yang lainnya. Untuk itu, tujuan artikel ini adalah mendeskripsikan hasil evaluasi kegiatan diseminasi produk hasil pengembangan blended learning berbasis schoology. Deskripsi hasil evaluasi tersebut akan meliputi kualitas penerapan blended learning dan motivasi belajar mahasiswa-atlet. Selain itu, variabel gender, jenis cabang olahraga, dan asal universitas akan dianalisis dalam mengidentifikasi motivasi mahasiswa-atlet saat mengikuti blended learning berbasis schoology.

\section{METODE}

Penelitian ini termasuk dalam penelitian deskriptif yang berusaha untuk menjelaskan kualitas blended learning berbasis shoology saat kegiatan diseminasi di empat universitas, yaitu Universitas Jambi, Universitas Pendidikan Ganesha, Universitas Negeri Yogyakarta, dan Universitas Negeri Makassar. Jenis keterlibatan universitas tersebut dalam bentuk join research dalam menerapkan model blended learning berbasis schoology. 


\section{Subjek Penelitian}

Perekrutan subjek penelitian dilakukan oleh dosen yang bersedia melakukan join research dalam menerapkan model blended learning berbasis schoology untuk perkuliahannya. Jumlah mahasiswa yang terlibat tergantung pada jumlah mahasiswa-atlet yang sedang memprogram matakuliah dosen yang bersangkutan. Akhirnya, sebanyak 59 mahasiswa bersedia terlibat dalam penelitian ini dengan rincian karakteristik seperti dalam tabel 1 sebagai berikut.

Tabel 1. Karakteristik subjek penelitian

\begin{tabular}{llc}
\hline \multicolumn{1}{c}{ Parameter } & \multicolumn{1}{c}{ Isi } & Jumlah \\
\hline Total subjek & & 59 \\
Gender & Laki-Laki & 39 \\
& Perempuan & 20 \\
Jenis Olahraga & Beregu & 22 \\
& Individu & 37 \\
& Universitas Jambi & 20 \\
Universitas & Universitas Pendidikan Ganesha & 16 \\
& Universitas Negeri Yogyakarta & 12 \\
& Universitas Negeri Makassar & 11 \\
\hline
\end{tabular}

Subjek penelitian adalah mahasiswa angkatan 2019, 2018, 2017, dan 2016 dari fakultas berbasis ilmu keolahragaan yang berstatus sebagai mahasiswa-atlet yang aktif dalam pemusatan latihan tingkat daerah (kabupaten dan provinsi) dan nasional.

\section{Prosedur}

Penawaran penerapan blended learning berbasis schoology diberikan kepada empat universitas dengan satu matakuliah yang disediakan yaitu matakuliah Atletik. Para dosen matakuliah Atletik diberikan pelatihan oleh tim untuk menggunakan aplikasi baik berbasis website (https://www.schoology.com/) maupun yang berbasis android (https://play.google.com/store/apps/details?id=com.schoology.app). Selain itu, juga telah dikembangkan aplikasi berbasis android khusus di https://play.google.com/store/apps/details?id=io.kodular.cahprdj2.ATLETI K. Tampilan aplikasi dalam Play Store sebagai berikut. 


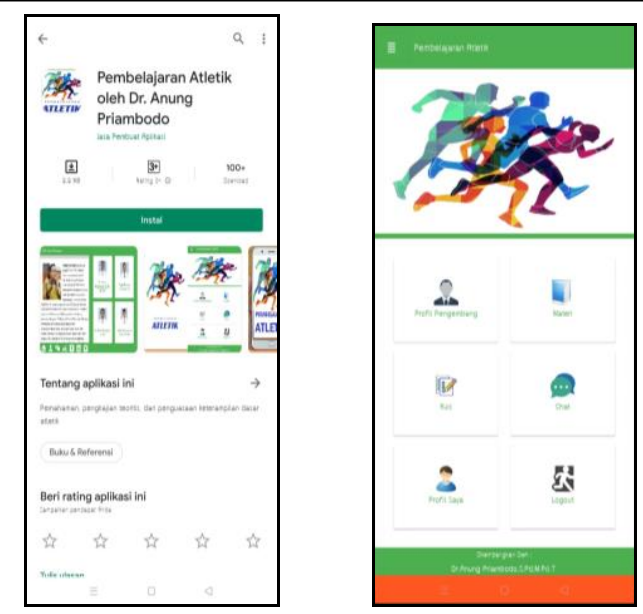

Gambar 1. Tampilan Aplikasi Blended Learning dalam Play Store

Para dosen yang mengikuti program join research ini selanjutnya menggunakan aplikasi untuk keperluan matakuliah atletik. Evaluasi penerapan blended learning berbasis schoology ini dilakukan selama dua bulan (setengah semester). Di tengah semester kualitas model dan motivasi belajar mahasiswa-atlet diukur. Selama penggunaan model, peneliti membuka layanan konsultasi dan bantuan kepada para dosen untuk pengembangan penggunaan model sesuai dengan kebutuhan proses perkuliahan yang sedang berlangsung di masing-masing universitas.

\section{Instrumen Penelitian}

Instrumen yang digunakan yaitu mengukur kualitas model dan motivasi belajar mahasiswa-atlet. Kualitas model diukur berdasarkan utility, feasibility, accuracy, and propriety bersumber dari instrumen evaluasi The Joint Committee on Standard for Educational Evaluation (JCSEE) (Handarini, 2000). Angket tersebut dimodifikasi untuk keperluan mengukur kualitas pelaksanaan model blended learning berbasis schoology. Sebanyak 26 butir pernyataan dibagi ke dalam empat aspek pengukuran yaitu utility sebanyak 7 butir, feasibility sebanyak 7 butir, accuracy sebanyak 7 butir, and propriety sebanyak 5 butir. Hasil pengukuran akan diinterpretasikan ke dalam kategori dengan menggunakan aturan kategori persentase standar yaitu: $0 \% \leq$ kurang 
sekali $\leq 20 \% ; 20 \%<$ kurang $\leq 40 \% ; 40 \%<$ cukup $\leq 60 \% ; 60 \%<$ baik $\leq$ $80 \% ; 80 \%<$ baik sekali $\leq 100 \%$.

Instrumen untuk mengukur motivasi belajar mahasiswa-atlet dikembangkan dari Academic Instrinsic Motivation yang terdiri atas dua komponen motivasi, yaitu motivasi intrinsik (tujuan penguasaan dan kebutuhan berprestasi) dan motivasi ekstrinsik (harapan penguasa, penerimaan teman sebaya, motivasi berkuasa, dan ketakutan untuk gagal) (Shia, n.d.). Dua jenis motivasi ini diyakini merupakan jenis motivasi yang dominan berperan dalam proses pembelajaran (Burstiando, 2015). Pengujian validitas dilakukan mulai dari validasi ahli, construct validity dengan teknik item total correlation, dan reliabilitas menggunakan cronbach's alpha. Hasil uji construct validity diperoleh 29 item valid dari total butir sebanyak 60. Pada motivasi intrinsik terdapat 12 butir valid dengan nilai korelasi sebesar 0.277-0.607 dengan nilai reliabilitas sebesar 0.782 . Selanjutnya pada motivasi ekstrinsik terdapat 17 butir valid dengan nilai korelasi sebesar 0.271-0.614 dengan nilai reliabilitas sebesar 0.787. Selanjutnya, data hasil pengukuran akan diinterpretasikan menggunakan aturan kategori nilai motivasi mahasiswa-atlet seperti pada tabel 1.

Tabel 1. Kriteria Analisis Data Angket Motivasi

\begin{tabular}{|c|c|c|c|}
\hline \multirow{2}{*}{ Keterangan } & \multicolumn{3}{|c|}{ Motivasi } \\
\hline & Instrinsik & Ekstrinsik & Total \\
\hline Jumlah pernyataan & 12 & 17 & 29 \\
\hline Nilai terendah & 12 & 17 & 29 \\
\hline Nilai tertinggi & 60 & 85 & 145 \\
\hline \multicolumn{4}{|l|}{ Kategori } \\
\hline Kurang Sekali & $x \leq 21.6$ & $x \leq 30.6$ & $X \leq 52.2$ \\
\hline Kurang & $21.6<x \leq 31.2$ & $30.6<X \leq 44.2$ & $52.2<X \leq 74.4$ \\
\hline Sedang & $31.2<X \leq 40.8$ & $44.2<X \leq 57.8$ & $74.4<X \leq 98.6$ \\
\hline Baik & $40.8<X \leq 50.4$ & $57.8<X \leq 71.4$ & $98.6<x \leq 121.8$ \\
\hline Baik Sekali & $50.4<X$ & $71.4<\mathrm{X}$ & $121.8<\mathrm{X}$ \\
\hline
\end{tabular}

\section{Teknik Analisis Data}

Pengolahan data kualitas model. Untuk memeriksa validitas pengukuran kualitas model digunakan Content validity ratio (CVR) dengan nilai kritis 0.3 (Ayre \& Scally, 2014). Selanjutnya nilai angket kualitas 
Vega Candra Dinata, Anung Priambodo, Agus Hariyanto, Kolektus Oky Ristanto, dan Bayu

Budi Prakoso

Evaluasi penerapan blended learning berdasarkan kualitas model dan motivasi belajar mahasiswaatlet

model dianalisis menggunakan proporsi untuk dikategorikan

menggunakan kategori standar untuk nilai persentase.

Pengolahan data motivasi belajar mahasiswa-atlet. Data akan dianalisis menggunakan deskriptif statistik yang selanjutnya akan dikategorikan menggunakan tabel 1. Untuk mengetahui perbedaan motivasi belajar mahasiswa atlet berdasarkan gender dan jenis olahraga digunakan $t$-test sedangkan berdasarkan universitas menggunakan OneWay Anova.

\section{HASIL}

Hasil analisis kualitas model blended learning berbasis schoology berdasarkan penilaian mahasiswa-atlet dapat dilihat dalam tabel 2.

Tabel 2. Pengujian Kualitas Model

\begin{tabular}{lccc}
\hline Komponen & Nilai Kualitas & Nilai Indeks CVR & Validitas \\
\hline Utility & $92 \%$ & 0.984 & Valid \\
Feasibility & $91 \%$ & 0.974 & Valid \\
Accuracy & $91 \%$ & 0.968 & Valid \\
Propriety & $92 \%$ & 0.993 & Valid \\
Rata-rata & $92 \%$ & 0.980 & Valid \\
\hline Catatan: nilai kritis indeks CVR sebesar 0.3 (Ayre \& Scally, 2014) & \\
\hline
\end{tabular}

Validitas pengukuran kualitas model dinyatakan valid dengan nilai indeks CVR untuk utility, feasibility, accuracy, and propriety sebesar 0.968-0.993 dan rata-rata indeks CVR sebesar 0.980>0.3. Artinya pengukuran dinyatakan memiliki ketepatan penilaian terhadap variabel yang dimaksud. Nilai utility sebesar $92 \%$ masuk dalam kategori baik sekali, feasibility sebesar $91 \%$ masuk dalam kategori baik sekali, accuracy sebesar $91 \%$ masuk dalam kategori baik sekali, and propriety sebesar 92\% masuk dalam kategori baik sekali. Sehingga nilai kualitas total sebesar $92 \%$ masuk dalam kategori baik sekali.

Hasil analisis deskriptif motivasi belajar mahasiswa-atlet menggunakan mean, standard deviation, minimum, maximum, skewness, and kurtosis dapat dilihat pada tabel 3. 
Tabel 3. Deskriptif Statistik Motivasi Belajar Mahasiswa-Atlet

\begin{tabular}{lccc}
\hline \multicolumn{1}{c}{ Morivasi } & Intrinsik & Ekstrinsik & Total \\
\hline $\mathrm{N}$ & 59 & 59 & 59 \\
Mean & 47.3 & 67.1 & 114.4 \\
Std. Deviation & 6.24 & 9.50 & 14.63 \\
Minimum & 36 & 49 & 87 \\
Maximum & 60 & 85 & 145 \\
Skewness & 0.469 & 0.150 & 0.396 \\
Kurtosis & -0.388 & -0.552 & -0.003 \\
\hline
\end{tabular}

Analisis deskriptif statistik menunjukkan bahwa nilai rata-rata motivasi intrinsik sebesar 47.3 (baik), motivasi ekstrinsik sebesar 67.1 (baik), dan total sebesar 114.4 (baik). Nilai skewness antara 0.15-0.469 dan kurtosis antara -0.552--0.003 menunjukkan bahwa bentuk distribusi data berbentuk simetrik (kurtosis and skewness $-1 \leq \mathrm{x} \leq 1$ ) atau dapat disimpulkan distribusi data normal (Meyers et al., 2013). Sehingga data hasil analisis deskriptif cukup untuk menjelaskan nilai dalam distribusi.

Perbedaan motivasi belajar mahasiswa-atlet berdasarkan gender dan jenis cabang olahraga dianalisis menggunakan t-test dapat dilihat pada tabel 4.

Tabel 4. Perbedaan Motivasi Berdasarkan Gender dan Jenis Olahraga

\begin{tabular}{llcccc}
\hline Variabel & & $\mathrm{t}$ & $\mathrm{df}$ & $p$ & Keterangan \\
\hline & Intrinsik & 1.048 & 57 & 0.299 & Sama \\
Gender & Ekstrinsik & 0.412 & 57 & 0.682 & Sama \\
(Laki-laki x perempuan) & Total & 0.714 & 57 & 0.478 & Sama \\
\hline & Intrinsik & 0.323 & 57 & 0.748 & Sama \\
Jenis Olahraga & Ekstrinsik & 0.606 & 57 & 0.547 & Sama \\
(Beregu x Individu) & Total & 0.531 & 57 & 0.597 & Sama \\
\hline
\end{tabular}

Analisis $t$-test menunjukkan bahwa $p$-value $>0.05$ untuk seluruh pengujian. Sehingga dapat disimpulkan bahwa tidak ada perbedaan motivasi belajar mahasiswa-atlet berdasarkan gender dan jenis olahraga saat mengikuti perkuliahan menggunakan blended learning berbasis schoology.

Perbedaan motivasi belajar mahasiswa-atlet berdasarkan universitas dianalisis menggunakan one way Anova dapat dilihat pada tabel 5 . 
Vega Candra Dinata, Anung Priambodo, Agus Hariyanto, Kolektus Oky Ristanto, dan Bayu

Budi Prakoso

Evaluasi penerapan blended learning berdasarkan kualitas model dan motivasi belajar mahasiswaatlet

Tabel 5. Perbedaan motivasi berdasarkan universitas

\begin{tabular}{lccccc}
\hline Motivasi & $\mathrm{N}$ & $\mathrm{df}$ & $\mathrm{F}$ & $\mathrm{P}$ & Keterangan \\
\hline Intrinsik & 59 & 3,55 & 0.832 & 0.482 & Sama \\
Ekstrinsik & 59 & 3,55 & 0.329 & 0.804 & Sama \\
Total & 59 & 3,55 & 0.451 & 0.718 & Sama \\
\hline
\end{tabular}

Analisis one way Anova menunjukkan bahwa $p$-value>0.05 untuk seluruh pengujian. Sehingga dapat disimpulkan bahwa tidak ada perbedaan motivasi belajar mahasiswa-atlet berdasarkan universitas saat mengikuti perkuliahan menggunakan blended learning berbasis schoology.

\section{PEMBAHASAN}

Pembahasan pertama dilakukan untuk membahas kualitas model blended learning berbasis schoology. Hasil validitas pada kualitas model berdasarkan utility, feasibility, accuracy, and propriety menunjukkan bahwa pengukuran kualitas model adalah valid $(0.98>0.3)$ (Ayre \& Scally, 2014). Pengukuran kualitas menggunakan empat aspek ini dianggap powerfull dalam bidang evaluasi (Tadayon, 2016). Selain itu, empat aspek tersebut telah diakui sebagai international standard untuk evaluasi (Yarbrough, 2017). Sehingga tidak berlebihan apabila produk yang sedang disebarluaskan ini merupakan produk yang memiliki kualitas yang tinggi (mean $=92 \%$, baik sekali). Penerapan produk dengan kualitas teruji seperti ini diharapkan dapat menyumbang pada ilmu pengajaran di perguruan tinggi dalam mendukung mahasiswa-atlet mendapatkan akses layanan pendidikan yang optimal sehingga dapat meraih sukses dalam dual karirnya.

Berikutnya, tujuan yang kedua adalah identifikasi motivasi belajar mahasiswa-atlet. Motivasi mahasiswa pengguna produk blended learning berbasis schoology masuk dalam kategori baik (mean=114.4). Temuan ini memperkuat hasil penelitian oleh Li et al., (2017) bahwa motivasi belajar mahasiswa berada pada level yang tinggi saat menerima pembelajaran dengan memanfaatkan blended learning. Hasil penelitian lainnya oleh Kintu et al., (2017) menyebutkan bahwa pengaturan blended learning dan karakteristik mahasiswa terbukti kuat sebagai prediktor yang kuat untuk 
hasil belajar. Motivasi belajar, termasuk dalam salah satu karakteristik yang kuat dalam menentukan keaktifan pembelajar dalam mengikuti proses pembelajaran (Chen, 2015). Keaktifan mahasiswa juga diyakini dapat membantu mahasiswa dalam memperdalam pemahaman materi pembelajaran (Suroto, 2018). Dengan bukti hasil evaluasi dalam artikel ini dapat diyakini bahwa blended learning berbasis schoology dapat menghadirkan motivational climate yang bagus. Pemilihan model pembelajaran yang tepat dalam menjaga motivational climate sangat penting agar motivasi belajar pembelajar terjaga (Granero-Gallegos et al., 2017) sehingga akan berdampak pada keaktifan pembelajar dalam mengikuti proses pembelajaran. Sehingga dapat disimpulkan bahwa dengan mempertinggi motivasi mahasiswa, pengajar dapat meningkatkan keaktifan mahasiswa yang berikutnya berdampak pada hasil belajar.

Hal ini menjawab masalah krusial berupa layanan optimal untuk mahasiswa-atlet yang memiliki motivasi belajar akademik rendah (Pedescleaux, 2010) dibandingkan dengan motivasi berprestasi di bidang olahraga (Guntoro et al., 2020). Konflik antara kegiatan berlatih dan belajar akademik dianggap sebagai gangguan yang nyata dalam memengaruhi motivasi belajar (Guidotti et al., 2013) yang selanjutnya berdampak pada rendahnya prestasi akademik mahasiswa-atlet (Levine et al., 2014). Untuk itu, pengajar perlu memberikan dukungan positif kepada mereka dengan cara memelihara motivasi belajar mahasiswa-atlet tetap tinggi untuk menumbuhkan sikap akademik yang positif. Mahasiswa-atlet dengan sikap akademik yang positif terbukti memberikan dampak pada prestasi akademik (Alahmed et al., 2017). Menerapkan blended learning merupakan salah satu cara untuk meningatkan motivasi belajar mahasiswa-atlet.

Temuan ini diharapkan memberikan dampak pada keyakinan pengajar untuk mau menerapkan blended learning. Saat ini, blended learning semakin meninggi penggunaannya karena dapat menghadirkan pembelajaran yang fleksibel dalam segi waktu dan tempat (Boelens et al., 2018). Dengan bukti validitas, kualitas, dan keberhasilannya dalam 
Vega Candra Dinata, Anung Priambodo, Agus Hariyanto, Kolektus Oky Ristanto, dan Bayu

Budi Prakoso

Evaluasi penerapan blended learning berdasarkan kualitas model dan motivasi belajar mahasiswaatlet

menjaga motivational climate untuk mahasiswa-atlet, tidak menutup kemungkinan model ini dapat digunakan untuk mahasiswa non-atlet. Terutama dalam menghadapi new normal yang saat ini sedang banyak dibicarakan. New normal adalah mengubah kebiasaan saat melakukan aktivitas normal dengan menerapkan protokol kesehatan guna mencegah penularan Covid-19 (Fajar, 2020). Pembelajaran jarak jauh dengan konsep belajar di rumah menjadi pilihan utama dalam new normal, konsep pembelajaran campuran (blended learning) menjadi pilihan ketika kondisi semakin membaik (Asikin, 2020).

\section{KESIMPULAN}

Validitas dan kualitas model dari hasil evaluasi kegiatan diseminasi ini cukup menjadi bukti bahwa model blended learning berbasis schoology ini tidak hanya dapat diterapkan oleh peneliti dalam lingkup subjek dan setting ujicoba yang kecil. Akan tetapi dosen di luar subjek ujicoba penelitian pun dapat memanfaatkan model ini untuk keperluan perkuliahan. Motivasi belajar mahasiswa-atlet masuk dalam kategori baik menunjukkan bahwa motivational climate dalam proses pembelajaran terjaga baik selama penerapan model blended learning berbasis schoology. Selain itu, tidak adanya perbedaan motivasi belajar mahasiswa-atlet ditinjau dari gender, jenis cabang olahraga, dan universitas menunjukkan bahwa blended learning berbasis schoology dapat diterapkan dalam berbagai kondisi dan jenis latar belakang. Khususnya untuk menjaga motivational climate guna mendukung mahasiswa-atlet belajar di bidang akademik.

\section{REFERENSI}

Alahmed, M. I., Yusof, A., Saidon, A., Borhannudin, A., \& Prihadi, K. (2017). Moderation role of attitude on the relationship between participation in competitive sports and academic performance of student-athletes in Saudi Arabia. IFMBE Proceedings, 58, 19-24. https://doi.org/10.1007/978-981-10-3737-5_5

Asikin, M. N. (2020, June 5). Sambut New Normal, Kemendikbud Siapkan Super Aplikasi

Pendidikan. https://www.jawapos.com/nasional/pendidikan/05/06/2020/sambut -new-normal-kemendikbud-siapkan-super-aplikasi-pendidikan/ 
Atmacasoy, A., \& Aksu, M. (2018). Blended learning at pre-service teacher education in Turkey: A systematic review. Education and Information Technologies, 23(6), 2399-2422. https://doi.org/10.1007/s10639-018-9723-5

Ayre, C., \& Scally, A. J. (2014). Critical values for Lawshe's content validity ratio: Revisiting the original methods of calculation. Measurement and Evaluation in Counseling and Development, 47(1), 79-86. https://doi.org/10.1177/0748175613513808

Best, M., \& MacGregor, D. (2017). Transitioning Design and Technology Education from physical classrooms to virtual spaces: implications for pre-service teacher education. International Journal of Technology and Design Education, 27(2), 201-213. https://doi.org/10.1007/s10798-015-9350-z

Boelens, R., Voet, M., \& De Wever, B. (2018). The design of blended learning in response to student diversity in higher education: Instructors' views and use of differentiated instruction in blended learning. Computers \& Education, 120, 197-212. https://doi.org/10.1016/J.COMPEDU.2018.02.009

Burstiando, R. (2015). Peningkatkan Motivasi Intrinsik dan Ekstrinsik Melalui Sport Education Model Pada Permainan Bolabasket. Jurnal SPORTIF : Jurnal Penelitian Pembelajaran, 1(1), 9-21. https://doi.org/10.29407/js_unpgri.v1i1.571

Castro, R. (2019). Blended learning in higher education: Trends and capabilities. Education and Information Technologies, 24(4), 2523-2546. https://doi.org/10.1007/s10639-019-09886-3

Chen, A. (2015). Operationalizing physical literacy for learners: Embodying the motivation to move. Journal of Sport and Health Science, 4(2), 125-131. https://doi.org/10.1016/J.JSHS.2015.03.005

Fajar, W.H. (2020, May 31). Mengenal Konsep New Normal I Indonesia.go.id.

https://indonesia.go.id/ragam/komoditas/ekonomi/mengenalkonsep-new-normal

Gaol, F. L., \& Hutagalung, F. (2020). The trends of blended learning in South East Asia. In Education and Information Technologies (Vol. 25, Issue 2, pp. 659-663). Springer. https://doi.org/10.1007/s10639-020-10140-4

Granero-Gallegos, A., Gómez-López, M., Rodríguez-Suárez, N., Arturo Abraldes, J., Alesi, M., \& Bianco, A. (2017). Importance of the motivational climate in goal, enjoyment, and the causes of success in handball players. Frontiers in Psychology, 8(DEC). https://doi.org/10.3389/fpsyg.2017.02081

Guidotti, F., Minganti, C., Cortis, C., Piacentini, M. F., Tessitore, A., \& Capranica, L. (2013). Validation of the Italian version of the Student Athletes' Motivation toward Sport and Academics 
Questionnaire. Sport Sciences for Health, 9(2), 51-58. https://doi.org/10.1007/s11332-013-0145-x

Guntoro, T. S., Kurdi, K., \& Putra, M. F. P. (2020). Karakter kepribadian atlet Papua: kajian menuju POPNAS ke-XV. Jurnal SPORTIF: Jurnal Penelitian Pembelajaran, 6(1), 40-58. https://doi.org/10.29407/js_unpgri.v6i1.13638

Handarini, D. M. (2000). Pengembangan Model Pelatihan Keterampilan Sosial bagi Siswa Sekolah Menengah Umum Terpadu. Universitas Negeri Malang.

Huba, M., \& Kozák, Š. (2016). From E-learning to Industry 4.0. International Conference on Emerging ELearning Technologies and Applications https://doi.org/https://doi.org/10.1109//CETA.2016.7802083 (ICETA)

Ibrahim, H. I., Jaafar, A. H., Kassim, M. A. M., \& Isa, A. (2016). Motivational Climate, Self-Confidence and Perceived Success among Student Athletes. Procedia Economics and Finance, 35, 503-508. https://doi.org/10.1016/S2212-5671(16)00062-9

Ibrahim, M. M., \& Nat, M. (2019). Blended learning motivation model for instructors in higher education institutions. International Journal of Educational Technology in Higher Education, 16(1), 1-21. https://doi.org/10.1186/s41239-019-0145-2

Kabassi, K., Dragonas, I., Ntouzevits, A., Pomonis, T., Papastathopoulos, G., \& Vozaitis, Y. (2016). Evaluating a learning management system for blended learning in Greek higher education. SpringerPlus, 5(1), 1-12. https://doi.org/10.1186/s40064-0161705-8

Kintu, M. J., Zhu, C., \& Kagambe, E. (2017). Blended learning effectiveness: the relationship between student characteristics, design features and outcomes. International Journal of Educational Technology in Higher Education, 14(1), 1-20. https://doi.org/10.1186/s41239-017-0043-4

Levine, J., Etchison, S., \& Oppenheimer, D. M. (2014). Pluralistic ignorance among student-athlete populations: a factor in academic underperformance. Higher Education, 68(4), 525-540. https://doi.org/10.1007/s10734-014-9726-0

Li, Y., Yang, H. H., Cai, J., \& MacLeod, J. (2017). College students' computer self-efficacy, intrinsic motivation, attitude, and satisfaction in blended learning environments. Lecture Notes in Computer Science (Including Subseries Lecture Notes in Artificial Intelligence and Lecture Notes in Bioinformatics), 10309 LNCS, 65-73. https://doi.org/10.1007/978-3-319-59360-9_6

Lim, C. P., Wang, T., \& Graham, C. (2019). Driving, sustaining and scaling up blended learning practices in higher education institutions: a proposed framework. Innovation and Education, 1(1), 1-12. 
https://doi.org/10.1186/s42862-019-0002-0

Maksum, A. (2018). Statistik dalam Olahraga. Unesa University Press.

Meyers, L. S., Gamst, G. C., \& Guarino, A. J. (2013). Performing Data Analysis Using IBM SPSS. John Wiley \& Sons, Inc.

Pedescleaux, J. (2010). Motivation factors as indicators of academic achievement: A comparative study of student-athletes and nonathletes academic and social motivation [University of Northern lowa].

https://scholarworks.uni.edu/cgi/viewcontent.cgi?article=1562\&con text=etd

Priambodo, A., Hariyanto, A., \& Dinata, V. C. (2020). The Development of Schoology-Based Blended Learning Model to Improve Student Motivation of National Training Center (PELATNAS) Athlete. 334338. https://doi.org/10.2991/ahsr.k.200214.089

Priambodo, A., Hariyanto, A., Dinata, V. C., Ristianto, K. O., \& Prakoso, B. B. (2020). Learning Need Assessment: Formulating BlendedLearning as Academic Services for Student-Athletes. 217-220. https://doi.org/10.2991/icracos-19.2020.46

Riciputi, S., \& Erdal, K. (2017). The effect of stereotype threat on studentathlete math performance. Psychology of Sport and Exercise, 32, 54-57. https://doi.org/10.1016/J.PSYCHSPORT.2017.06.003

Sandstedt, S. D., Cox, R. H., Martens, M. P., Ward, D. G., Webber, S. N., \& Ivey, S. (2004). Development of the Student-Athlete Career Situation Inventory (SACSI). Journal of Career Development, 31(2), 79-93. https://doi.org/10.1007/s10871-004-0566-5

Sarrab, M., Al-Shihi, H., Al-Manthari, B., \& Bourdoucen, H. (2018). Toward Educational Requirements Model for Mobile Learning Development and Adoption in Higher Education. TechTrends, 62(6), 635-646. https://doi.org/10.1007/s11528-018-0331-4

Shia, R. M. (n.d.). Academic Intrinsic 1 Running head: ACADEMIC INTRINSIC AND EXTRINSIC MOTIVATION AND METACOGNITION Assessing Academic Intrinsic Motivation: $A$ Look at Student Goals and Personal Strategy.

Suroto. (2018, July 1). Active Learning Model in Track and Field Course for Pre-service Physical Education Teacher. Proceedings of the 2nd Social Sciences, Humanities and Education Conference: Establishing Identities through Language, Culture, and Education (SOSHEC 2018). https://doi.org/10.2991/soshec-18.2018.68

Tadayon, N. (2016). Evaluating Program Assessment Report. Proceedings of the International Conference on Frontiers in Education: Computer Science and Computer Engineering (FECS), 173-178. https://search.proquest.com/openview/c0644e3fd073e62871cabf3 9ab4002f3/1 ?pq-origsite $=$ gscholar $\& \mathrm{cbl}=1976352$ 
Vega Candra Dinata, Anung Priambodo, Agus Hariyanto, Kolektus Oky Ristanto, dan Bayu

Budi Prakoso

Evaluasi penerapan blended learning berdasarkan kualitas model dan motivasi belajar mahasiswaatlet

Wuryaningsih, W., Susilastuti, D. H., Darwin, M., \& Pierewan, A. C. (2019). Effects of Web-Based Learning and F2F Learning on Teachers Achievement in Teacher Training Program in Indonesia. International Journal of Emerging Technologies in Learning (IJET), 14(21), 123-147. https://doi.org/https://doi.org/10.3991/ijet.v14i21.10736

Yao, C. (2019). An investigation of adult learners' viewpoints to a blended learning environment in promoting sustainable development in China. Journal of Cleaner Production, 220, 134-143.

Yarbrough, D. B. (2017). Developing the program evaluation utility standards: Scholarly foundations and collaborative processes. Canadian Journal of Program Evaluation, 31(3), 284-304. https://doi.org/10.3138/cjpe.349 